Article

\title{
Beef Cattle Production Systems in South Pantanal: Considerations on Territories and Integration Scales
}

\author{
Ana Gabriela J. Araujo ${ }^{1}$, Antônio M. V. Monteiro ${ }^{2}$, Gilvan S. Oliveira ${ }^{3}$, Luiz T. Silva ${ }^{1}$, \\ Luan M. Grilo ${ }^{1}$, Débora L. S. Teixeira ${ }^{1}$ and Monica T. Souza ${ }^{4, *}$ \\ 1 Earth System Science Center (CCST)—National Institute for Space Research (INPE), Presidente Dutra Road, \\ Km 40, Cachoeira Paulista, SP 12630-000, Brazil; ana.araujo@inpe.br (A.G.J.A.); luiz.tadeu@inpe.br (L.T.S.); \\ luan.grilo@inpe.br (L.M.G.); debora.teixeira@inpe.br (D.L.S.T.) \\ 2 Earth Observation General Coordination (CGOBT) - National Institute for Space Research (INPE) \\ Astronautas Avenue, 1758, São José dos Campos, SP 12227-010, Brazil; miguel@dpi.inpe.br \\ 3 Center for Weather Forecasts and Climate Studies (CPTEC)—National Institute for Space Research (INPE), \\ Presidente Dutra Road, Km 40, Cachoeira Paulista, SP 12630-000, Brazil; gilvan.sampaio@inpe.br \\ 4 Engeotec Geotecnologia, Madrid Street, 50-Jardim Augusta, São José dos Campos, SP 12216-750, Brazil \\ * Correspondence: monicatatiane@hotmail.com or anaaraujogeo@gmail.com; Tel.: +55-12-3186-9273
}

Received: 7 August 2018; Accepted: 31 August 2018; Published: 12 December 2018

\begin{abstract}
Pantanal is one of the largest wetlands in the world. In its southern portion, it hosts significant beef cattle ranching, having a herd of 4,832,200 head of cattle in 2016 (IBGE, 2018). Yet it presents intra-regional differences and complementarities. This article discusses such current territory definition, focusing on cattle ranching in Pantanal, considering its forms of occupation, agents, and its intra-regional flow of cattle. This recognition is essential for the identification of the arrangements developed in the territory, its temporal dynamics and spatial strategies, assuming different forms of interaction with the environment. In order to identify multiple livestock territories and their logics of action, data grouped into four dimensions were considered: (i) agents, (ii) product, (iii) space used, and (iv) flows and circulation, approached in different scales (farms, municipal and units of landscape floodplain/plateau). The analyzes show different forms of domination and territorial appropriation, continuous and discontinuous, permanent and temporary. Mapping of cattle territories in the South Pantanal identified a scenario of multiterritoriality. While maintaining its "nursery" profile, it presents more intensive arrangements with the rearing and fattening phases. New territorialities represented by external agents and the fragmentation of old properties has genereted a new mapping of the "used spaces" for cattle breeding and posed new challenges for the maintenance of the traditional cattle production systems in the region.
\end{abstract}

Keywords: pantanal wetlands; cattle breeding; food security; network territories; multiterritoriality

\section{Introduction}

The global food system, after many years of consistent technological advances in its production and distribution subsystems, has been claimed to be under pressure. The accelerated and differentiated rates and effects of climatic, environmental, socio-economic, cultural and political changes around the world have made more explicit the overconsumption and undernutrition sides of the nutritional global system. In 2018 the classical masterpiece on food and population of Josué de Castro, The Geopolitics of Hunger, will complete 66 years since its publication [1]. De Castro examined, in great depth back in 1952, the effect of political, economic, and social forces on the food available for consumption considering a variety of population groups over a diversity of geographical regions. He demonstrated at that time, with plenty of data in support of his argument, that it was not the geography or natural 
factors per se which had caused the observed collective undernutritional situations in many places around the world. Societies organized on a basis of social and economic inequalities and making unappropriated uses of their natural resources were at the root of the problem.

In certain aspects, in particular those related to urbanization, climate and environment, times have changed. The United Nations' World Population Prospects: The 2017 Revision [2] pointed out that $55 \%$ of the world's population lived in urban areas, a proportion that is expected to increase to $68 \%$ by 2050 . Together with fast urbanization rates, the intensity and frequency of extreme weather events have risen fiercely [3] and, livestock is the largest land use sector on Earth and an important driver of forest cover conversion. Although, these are new and very important facts, Josué de Castro's ideas on bad socio-economic arrangements that are coupled with inappropriate ways of dealing with disruptions caused by weather extremes is the perspective of this paper to analyse the overall risks of a specific food production chain. This food chain production system involves tradition and modernities acting upon the land system configurations related to livestock products in a very peculiar region in Brazil, the South Pantanal in Mato Grosso do Sul.

Brazil owns the second largest cattle herd in the world, with 212.3 million heads, with India being the first worldwide owner. The states of Mato Grosso, Minas Gerais, Goiás, Mato Grosso do Sul, and Pará together account for more than half of all Brazilian livestock (54.1\%) [3]. The floodplain of the Upper Paraguay Basin (UPB) has an area of $138,183 \mathrm{~km}^{2}$, and it is located in the center of South America, extending beyond the borders of Brazil, Bolivia, and Paraguay. The region presents geoecological specificities that express varied landscapes, configuring an environment subject to the pulse rate of annual floods [4].

Calf breeding is the most important factor in beef cattle production in the Pantanal of Mato Grosso do Sul. The state owns $65 \%$ of the total area of the Pantanal wetlands [5]. The South Pantanal could be defined as a "nursery", given its significant production of calves in an extensive system tsupplying the national meat production chain [6]. The activity is extensive and is characterized by the frequent displacement of animals according to the availability of native pastures, which are the basis of cattle production and always renewed with the passage of water [7-9].

In addition to the flood pulse that also determines the conditions of access and circulation, the Pantanal inhabitant constructs his territorial strategies to maintain livestock production [10]. For a long time, it was subject to a territorial logic with little control over the herds, which were left loose in the vast native fields and displaced as far as needed, between the plain or the higher lands, like saws and the border plateau. However, new forms of production with more intensive logics in animal and land management have been revealed recently. Since the 1990s, the South Pantanal has been restructuring its beef cattle. Different production systems are a recognized sector [11-13].

First is the system traditionally developed for centuries. It is characterized by a "domestic" administration in which capital investments and innovations are carefully dosed by each breeder [11], with less use of inputs and technologies [14]. In this system, breeding goals, such as the number of animals, planning of the breeding season (if any), marketing period and sale of the cattle are varied according to the seasonality of annual floods [15]. According to Araujo et al. [11], this production system is developed from the "empiria of the pantaneiro individual". It is represented mostly by heirs of "pioneering" families who settled in the South Pantanal favored by the colonial government in the eighteenth and nineteenth centuries and territorialized cattle as the main form of land use and socioeconomic activity [16]. In parallel, innovations and ruptures are observed in the system of production of farms with higher capital increases, and more streamlined management and administration, in tune with the recent expansion and intensification of the beef production chain in Brazil. In these systems, there is greater use of exotic pastures (more resistant to environmental variability), new animal breeds, and the sale of precocious animals. The stages of rearing and fattening are more prominent. They are called modernized, when implementing diversified production (in a certified organic system or in multifunctional farms that also develop tourism), led by social and economic agents, usually from other locations [17]. 
These systems transformed the Pantanal landscape with innovations and ruptures to traditional logic [7]. These are technical changes geared towards intensive production, such as more business management, the arrival of skilled labor, and investments in modern pasture management technologies, sanitary, reproductive and nutritional management of herds, according to the imperative of productive activities found outside the Pantanal. On the other hand, they also show technical changes that aim to balance production with the support of the Pantanal landscape. They represent another bias and contribute new meanings to the productive space and products of the regional livestock, by revaluing native vegetation and traditional knowledge [18]. The organic and biodynamic systems make use of the identity of the Pantanal cattle, considered a vector of socio-cultural formation of the region and, therefore, know-how that must be conserved and transformed into product differential for new markets [10,11].

The diversity of beef cattle production systems in the South Pantanal demands a greater understanding of their territorial arrangements. According to Araujo [7], they reveal different dynamics of (re)organization of "territories of use" of the South Pantanal activity that articulate different landscapes, both in the seasonally flooded plain and in the plateau areas of borders, and deserve an integrated look.

In general, regional livestock studies focus on analyses of political-administrative scales or environmental cuts that do not address intra-regional spatial differences and complementarities. From the perspective of territorial planning, there is a need to find instruments and methods adjusted to different scales, covering up the differences between lowland and upland edges of municipalities, as well as the South Pantanal homogeneous region.

The classical definition of the territory concept in geography is a material space, continuous and limited by established borders. This classical view was mainly applied to traditional manners of territories in national states, as a political-administrative delimitation, with little space-time mobility [19].

However, socio-spatial processes from the turn of the 20th century to the 21st developed under the ages of globalization reflect many territorial, material or immaterial dynamics in fields such as economics, politics, culture and identity, and multiscales in space and time.

More recently, Haesbaert [20-24] conceives territory as a set of historical-social relations which involve space domination (more concrete-functional) and appropriation (more symbolic). The author considers the perspective of power that domination and appropriation imply in the political-state dimensions, be it economical or cultural. In this manner, the author contributes to the notion of multiterritoriality, which would happen through there being simultaneously several territories in the same special plane, and proposes the need to map out the multiple territories that are seen in the current movement of societies [21,25].

Thus, "multiterritoriality" occurs in situations where agents experience multiple territories at the same time. One example is the so-called network territories, built on the advantage of the facilities of rapid circulation and instant communication that allow the access, control and management of different locations without the need for physical presence. These territories are carried out in the articulation of discontinuous areas, either at the municipal or world scale, directly and/or remotely. Thus, in the physical and continuous space, a horizon of multiple territories is drawn, where the same space is cohabited or controlled by different agents/intentions [21].

This work deals with the material dimension of the territory of the cattle breeding area of the Pantanal of Mato Grosso do Sul. Such analysis is necessary as the activity reflects traditional territorial logics in a network which make the use of areas temporary and surpasses the municipal borders and of the Pantanal region, whether due to management or commercialization of cattle herds [8], or as presenting multiple territories, considering the current diversity of agents and productive landscapes in the region [7].

Since pantaneira bovine farming shows socio-spatial arrangements that denote a historical "nomadism" of frequent displacements, occupation and use of space with variable length and duration 
and network articulations, some questions are posed: how are the livestock territories of the South Pantanal? Where are they located in the regional space? What are the logics of territorial occupation in terms of handling and marketing of products?

The investigation of these territorial logics from the point of view of the different scales of area integration and the use of native lowland pastures contributes to the governance of land and food systems, and has implications for the maintenance of ecosystem services in the Pantanal Sul, an ecosystem that is singular and fragile. In addition, it contributes to regional food security-related studies, considering the region's importance in meat production.

Thus, the main objective of this work was to identify continuous and discontinous territorial manners of beef cattle breeding in the South Pantanal, according to Haesbaert's theoretical and conceptual proposal $[20,21]$, considering a set of variables available in the information systems related to the agents, space used and circulation flow of products of the regional cattle breeding, as well as to characterize differences in its production systems at inter-municipal and intra-regional spatial scales (plain and plateau).

\section{Materials and Methods}

The study area includes seven municipalities in the Mato Grosso do Sul State: Aquidauana, Corumbá, Coxim, Ladário, Miranda, Porto Murtinho, and Rio Verde de Mato Grosso, which together make up $99.48 \%$ of the total area of the Pantanal Mato Grosso do Sul State, that is, 123,13 thousand $\mathrm{km}^{2}$ [5]. Figure 1 shows the analyzed municipalities and the plain portions of the wetland, as well as the plateau lands of each of them.

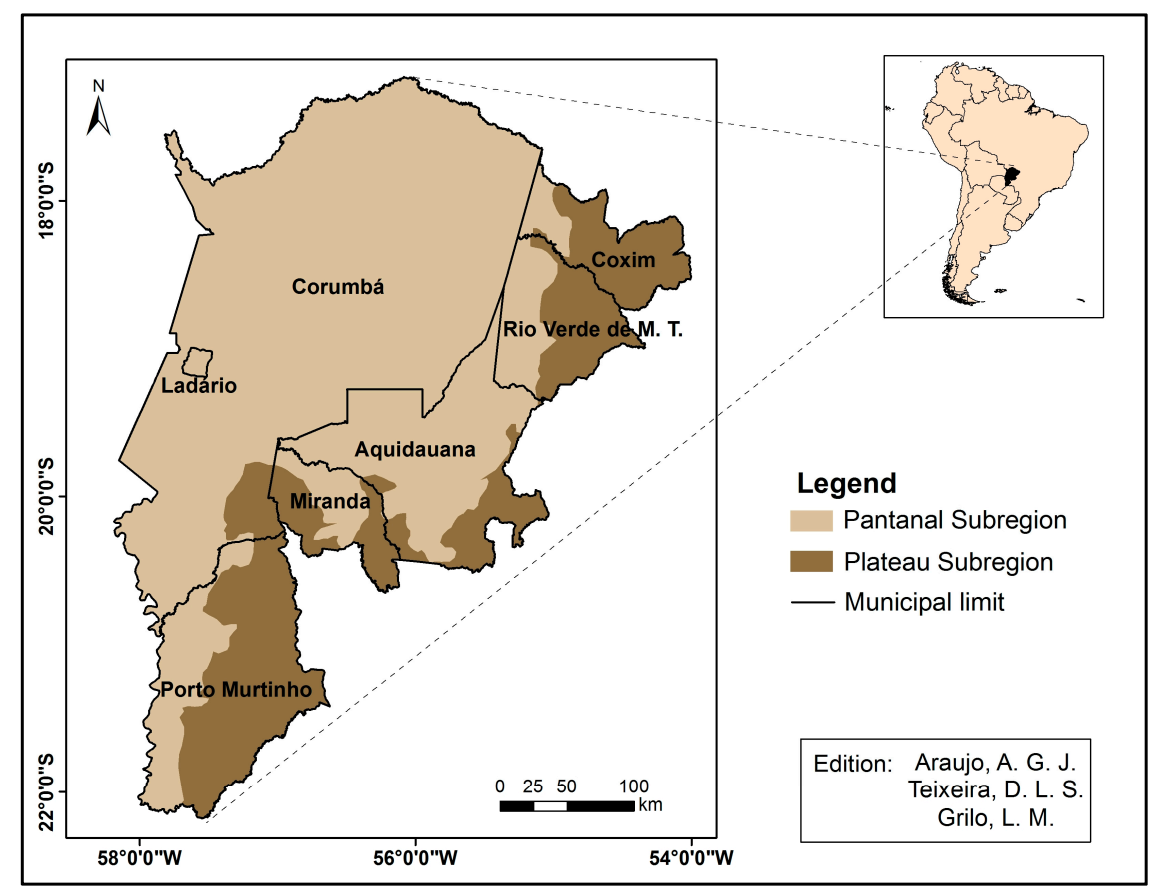

Figure 1. South Pantanal area. Source: Adapted from Silva and Abdon (1998).

In order to produce evidence of territorial logics and a productive spatial structure that reflects what can be termed network-territories, an observational methodological approach was used of the material-functional dimension of the territories of regional livestock. Each set of corresponding variables, detailing the spatial and temporal units, metrics and information systems, is presented in Figure 2 and is described below. 


\begin{tabular}{|c|c|c|c|c|c|c|}
\hline \multirow[b]{2}{*}{ Properties } & \multirow[b]{2}{*}{ Variables } & \multicolumn{2}{|c|}{ Space unit } & \multirow[b]{2}{*}{ Metric } & \multirow[b]{2}{*}{$\begin{array}{l}\text { Information } \\
\text { system }\end{array}$} & \multirow[b]{2}{*}{ Year } \\
\hline & & & & & & \\
\hline Agent & $\begin{array}{l}\checkmark \text { Administrative Profile } \\
\text { (Individual } \times \text { Company) }\end{array}$ & & Yes & $\begin{array}{l}\text { Rural property owners ID. } \\
\text { (n.) }\end{array}$ & 1 & 2016 \\
\hline Product & $\begin{array}{l}\checkmark \text { Main product (rising, } \\
\text { reproduction and fattening) }\end{array}$ & Yes & & Herd composition (n.) & 2 & $2005-2014$ \\
\hline Used space & $\checkmark \%$ Native Pasture $\times$ Planted & Yes & Yes & $\begin{array}{l}\text { Polygons (ha) } \\
\text { Size of rural properties (ha) }\end{array}$ & $\begin{array}{c}\text { Silva et al., } 2011 \\
1 \\
\end{array}$ & $\begin{array}{l}2007 \\
2015 \\
\end{array}$ \\
\hline $\begin{array}{c}\text { Management } \\
\text { techniques }\end{array}$ & $\begin{array}{l}\checkmark \text { Stocking Rate (animal units/ha) } \\
\checkmark \text { Intensification Indicators }\end{array}$ & $\begin{array}{l}\text { Yes } \\
\text { Yes }\end{array}$ & & $\begin{array}{l}\text { Herd/pasture (animal/ha) } \\
\text { Herd composition (n.) }\end{array}$ & $\begin{array}{c}2 / \text { Silva et al. } 2011 \\
2\end{array}$ & $\begin{array}{c}2014 / 2007 \\
2014 \\
\end{array}$ \\
\hline $\begin{array}{l}\text { Flow and } \\
\text { circulation }\end{array}$ & $\begin{array}{l}\checkmark \% \text { Car transport } x \text { on foot } \\
\checkmark \text { Market Connections }\end{array}$ & $\begin{array}{l}\text { Yes } \\
\text { Yes }\end{array}$ & & $\begin{array}{l}\text { Traffic herd (n.) } \\
\text { Traffic herd (n.) }\end{array}$ & $\begin{array}{l}3 \\
3 \\
\end{array}$ & $\begin{array}{r}2007-2014 \\
2007-2014 \\
\end{array}$ \\
\hline
\end{tabular}

Figure 2. Variables that represent the properties strutuctures of the cattle breeding of the South Pantanal. 1 Land Collection (SIGEF)/Brazilian National Institute of Colonization and Agrarian Reform (INCRA), 2 Mouth Disease Vaccination Campaign by Animal and Plant Health Defense Agency of Mato Grosso do Sul State (IAGRO) 3 Animal Movement Permits by Animal and Plant Health Defense Agency of Mato Grosso do Sul State (IAGRO)—Source: Adapted from Araujo (2018).

Identification of the agents was obtained from the SIGEF/INCRA, from 2016. This database allowed the classification of administrative profiles in the scale of the rural property, indicating the ownership of farms by people and corporate agents (legal entity) and, indirectly, illustrating the sense of innovation and multiterritoriality observed in the South Pantanal.

The product dimension refers to the volumes of bovine animals broken down by age ranges on the scale of intra-municipal sub-regions in 2014. Data were considered as indicative of the regional livestock products from the proportion of each production phase: cows and calves from 0 to 12 months, rearing (calves from 12 to 24 months), and fattening (males over 24 months). This database allowed investigation of the composition of the herds in each portion of the plain and plateau, that is, the differentiation of production modes in terms of stays and ruptures taking in the intra-regional space. Age classes and spatial scale refer to the methodology of the Animal Movement Permits and Mouth Disease Vaccination Campaign by IAGRO. These records are the best data available as they reach more than $98 \%$ of the cattle herd in the region [26].

The dimension space used is represented by two variables: 1 . The land use and land cover map, based on the mapping of the GeoMS project [27], which allowed the quantification of the native and planted pasture areas of the South Pantanal on a scale 1:100,000. This latter class of use can be considered as an aspect of innovation and intensification of the productive systems of the regional livestock, as it is comparatively more resistant to floods and presents greater capacity of support by number of head of cattle, reflecting, thus, the rationalization of the productive space and being an indicator of innovation [17]. In the southern Pantanal, planted pastures can be used in small areas, such as reserves and complements in critical periods of floods or droughts of native pasture restriction, indicating an adaptive strategy to seasonality [28]. 2. Rural properties, based on INCRA's Land Collection, which allowed the identification of real production units, rural establishments, specifically standard area and ownership of more than one farm in the region, indicative of the territorial logic in network.

On management techniques, in general the secondary data regarding this property are available at the municipal scale [29]. This spatial scale makes it impossible to identify and analyze permanences, elements of innovations and ruptures in the intra-regional space of the municipalities. In view of this, it was considered necessary to cross-reference other data available at the subregional scale. The stocking rate of the pastures of each intra-municipal sub-region was generated in individual units from the intersection in the Geographic Information System between the pasture geometries and information on the size and composition of the herd, that is, the animal/hectare measure, being the expression of the degree of intensification of the productive space in relation to its occupation. 
Finally, bovine transit was characterized in the period between 2007 and 2014, using data from the Animal Care System of the State Agency of Plant and Animal Sanitary Defense of Mato Grosso do Sul (SANIAGRO). The system is based on the records of Animal Transit Guides related to the control of the flow of cattle, according to Administrative Rule no. 3.505/15 and Law 5741/06 [30,31]. The data are also on the sub-regional intra-municipal scale and provided monthly information on the volume and sex of displaced animals, origin and destination of each transit, flow purpose and means of transport. The information allowed for the refinement of the analyses in terms of differences and complementarities between the Pantanal and the South Pantanal, as well as the cartography of their connections with other localities, presumed here as indicative of the expansion of the regional product commercialization networks.

Specifically, the methodological procedures performed were: 1. A literature research on land occupation and consolidation of livestock in the region; 2 . data collection; 3 . organization and mining of collected data in a geographic database; 4 . spatialization of variables; 5 . selection of query variables on the spatial database; and 6. synthesis in maps and tables for analysis.

\section{Results and Discussion}

Over time, cattle breeding has been receiving waves of innovation. Figure 3, based on several authors, explains the evolution of the attributes that characterize South Pantanal beef cattle herding as the product, markets, outlets, technical system, and elements of the organization of the territory, the elements of materiality that comes from building the functional dimension of these production territories.

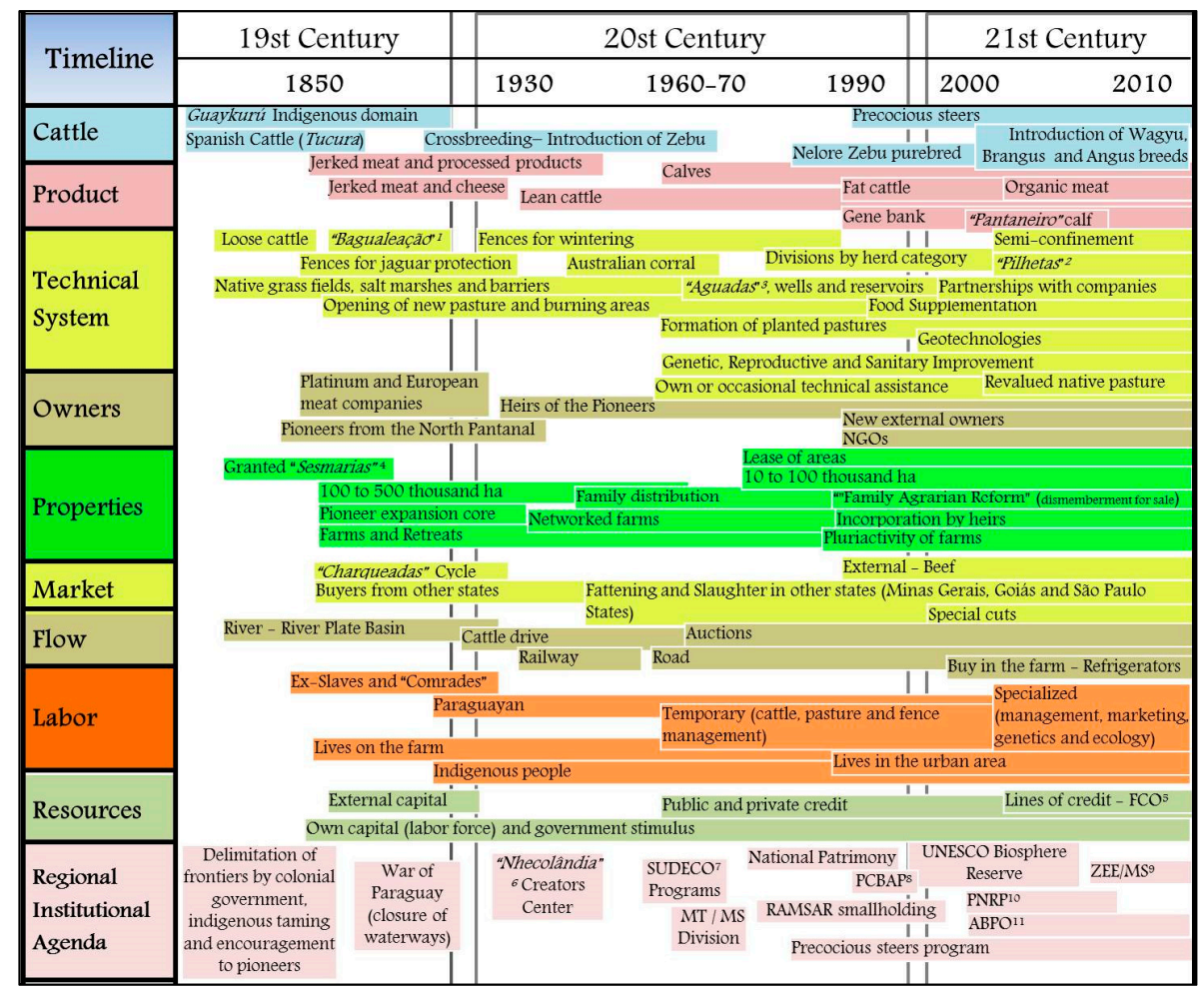

Figure 3. Timeline of cattle breeding in the South Pantanal. Note: ${ }^{1}$ Capture of animals by bundling and sale of "lots" (groups of cattle). ${ }^{2}$ Mobile tank with potable water for the herd, usually made of plastic. ${ }^{3}$ Species of temporary lake, natural or artificial. ${ }^{4}$ Distribution of land for agricultural production. ${ }^{5}$ FCO: Central-West Funding Fund. ${ }^{6}$ Pantanal sub-region in the municipality of Corumbá. ${ }^{7}$ Central-West Development Superintendence. ${ }^{8}$ Conservation Plan for the Alto Paraguai Basin.

${ }^{9}$ Economic-ecological zoning of Mato Grosso do Sul State. ${ }^{10}$ Pantanal Regional Natural Park.

${ }^{11}$ Brazilian Association of Organic Livestock. Source: Adapted from Araujo (2018). 
Intra-municipal differences were identified through the profile of farms. Figure 4 shows the differences between the interior of the midwest, which maintains traditional and larger farms, and transition areas with the border plateau (east, north-east and south-east), which shows a pattern of smaller farming areas.

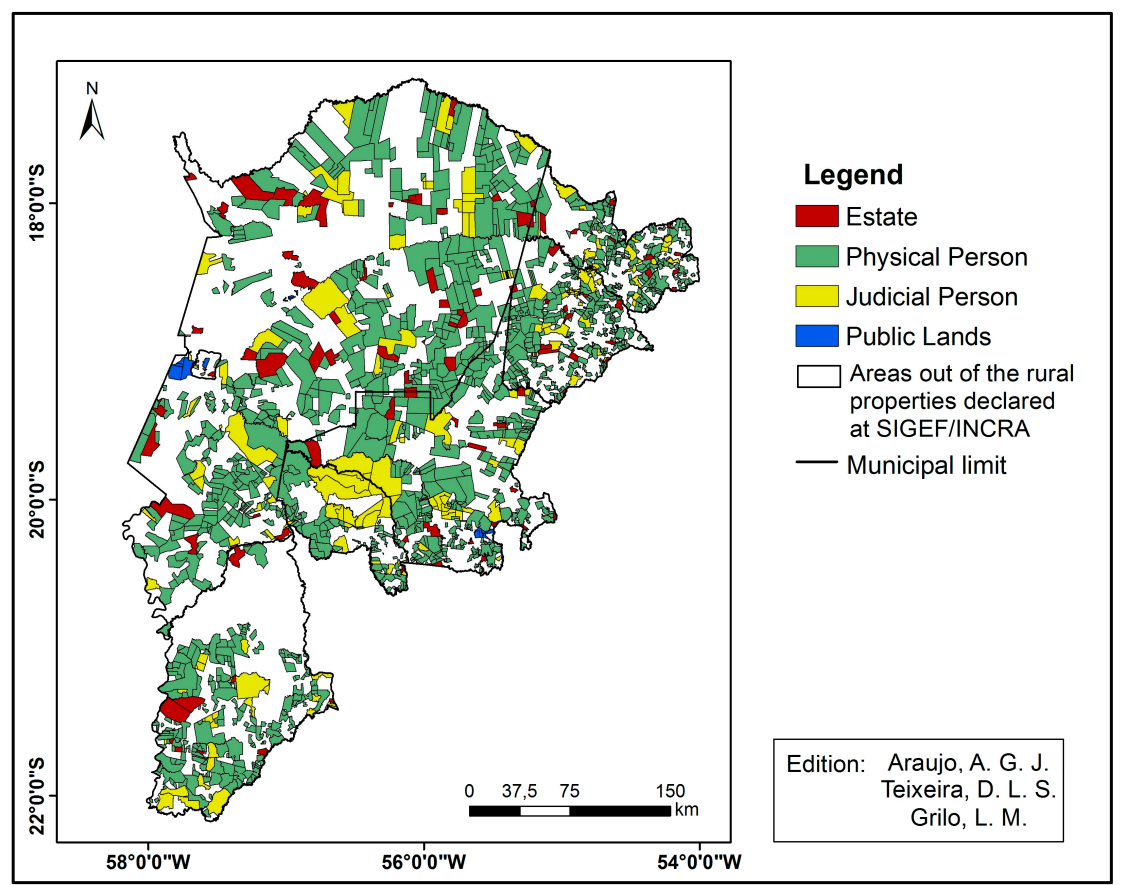

Figure 4. Rural properties in the municipalities of the South Pantanal according to the administrative profile. Source: Araujo (2018).

Figure 4 also shows the administrative profile of the owners and suggests a scenario of multiple territories with different functional arrangements that own territorialities [7] that create a kaleidoscopic landscape [18]. Ownership is strongly felt throughout the study area, indicating that the South Pantanal is still a private space, seen by the low occurrence of public lands. There is notable ownership of legal entities, ranging from cooperatives, agricultural companies, holdings and NGOs, with emphasis on the municipality of Miranda, in addition to the concentration in regions of Aquidauana and the center and south of Porto Murtinho.

In this discontinuous spatial logic, farms represent the nodes of a network (s) and exemplify one of the adaptive strategies of the activity in the region, which implies a "nomadic" territory, because it is in frequent movement, although it is based on private property. From the identification of the owner, there are 183 property networks, that is, 183 owners who own the livestock network in the South Pantanal. In addition to the networks, it was possible to map the processes of incorporation of neighboring lands (Figure 5). Forms that represent the recent land changes with fragmentation of the old farms, due to inheritance and sale. Both work as elements of the Pantanal's cattle breeding territorial arrangement, that is, the materiality that has been building the material-functional dimension of the activity [32,33].

In spite of the permanence and predominance of the large farms in the wetlands, the presence of productive units with a smaller area may suggest the material deterritorialization of the traditional bovinoculture of the region, a process caused by the fragmentation of farms due to inheritance and sale to external agents [17]. This recent territorial dynamic, locally called "family agrarian reform", is seen as a threat to the historically developed adaptive strategy [34]. According to Queiroz Neto [35], the distribution of farms leads to the increase of fences, which prevents the circulation of livestock to shelter and represents a point of vulnerability to the regime of annual floods and droughts. In terms of livestock production, it is possible to observe the difference in composition between wetlands 
and plateaus, as well as the difference of intermunicipal profiles (Table 1). While Corumbá and the floodplains of Coxim and Aquidauana have a high proportion of animals used in the breeding phase: cows and calves, Miranda and Coxim, Aquidauana and Rio Verde de Mato Grosso have a higher proportion of animals at the lean steers aged 12 to 36 months (weaned calves, growing heifers and yearling steers), culled bulls and cows.

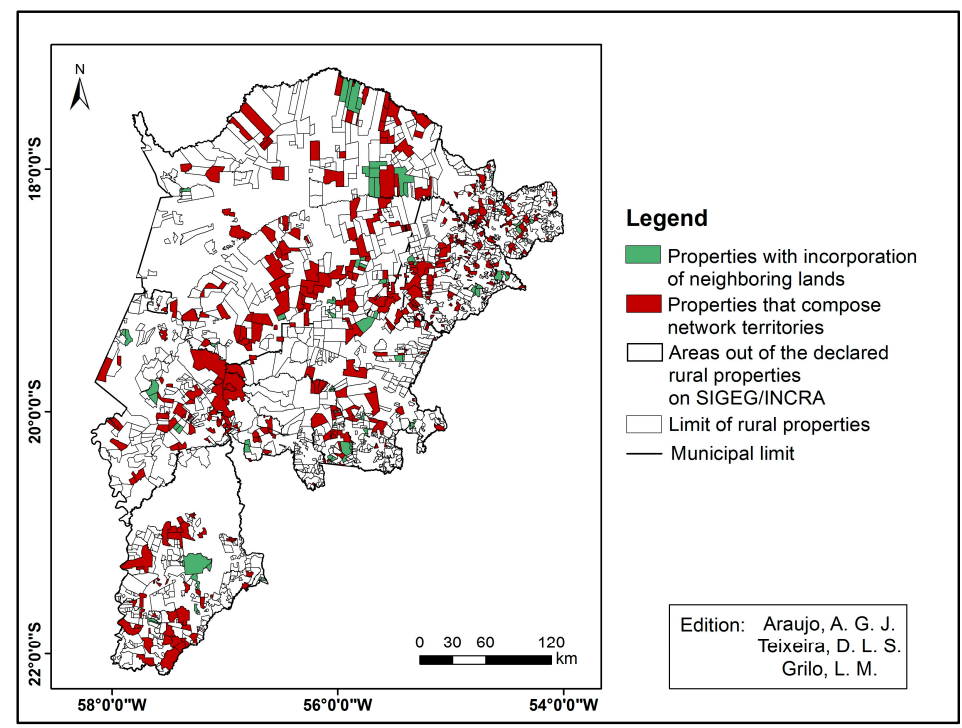

Figure 5. Networks-territory of the cattle breeding of the South Pantanal. Source: Araujo (2018).

According to the estimation of Carvalho et al. (2009), the categories of the herd in the modal system in the region of Corumbá are: calves: $29.40 \%$, heifers from 12 to 24 months (M): $11.14 \%$, steers from 24 to 36 months: $8.30 \%$, cows (calves: $32.94 \%$ and single: $15.99 \%$ ) and bulls: $2.23 \%$. It has no plateau sub-region, according to the methodology of the Vaccination Campaign. Source: IAGRO (2015). Data compiled and organized by Olinda B. M. Costa and Ana G. J. Araujo (2016).

The indicator pasture stocking rate of each intra-municipal sub-region evidences the presence of the traditional system for the lowest values, while the highest values represent the systems with higher pasture occupation, reflecting technical innovations in terms of more optimized pasture use (Figure 6).

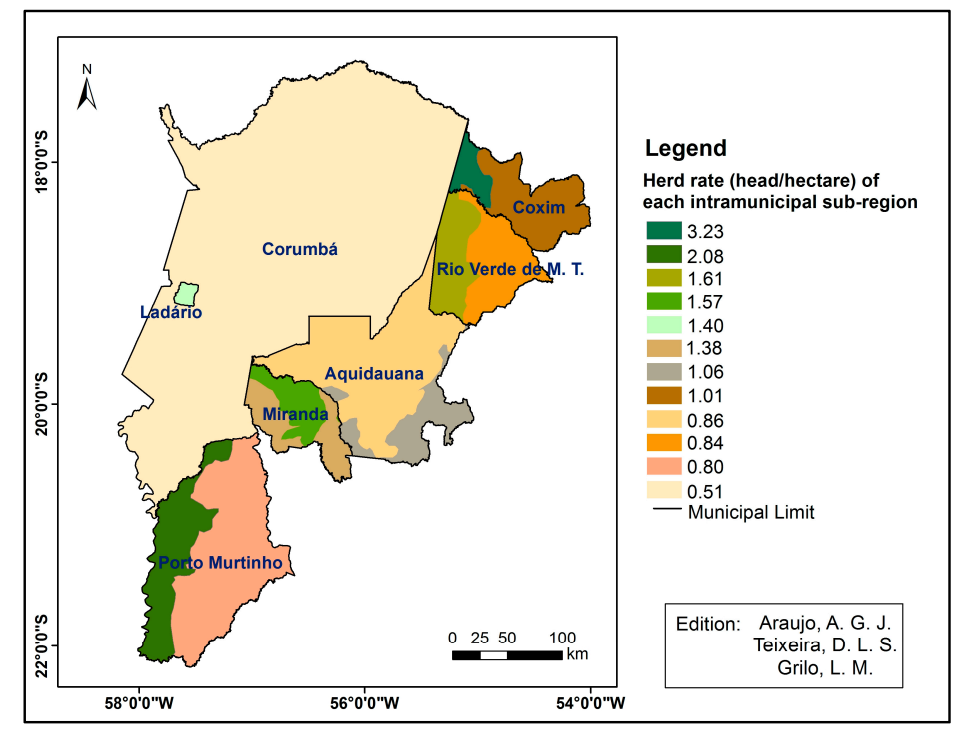

Figure 6. Pasture stocking rate by intra-municipal subregions of the South Pantanal. Sources: (2018). 
Table 1. Relative composition of South Pantanal herds in 2014 (\%).

\begin{tabular}{|c|c|c|c|c|c|c|c|c|c|c|c|c|c|c|c|c|c|c|}
\hline \multirow{3}{*}{ Municipality } & \multicolumn{9}{|c|}{ Plains } & \multicolumn{9}{|c|}{ Plateaus } \\
\hline & \multicolumn{4}{|c|}{ Females } & \multicolumn{4}{|c|}{ Males } & \multirow[b]{2}{*}{$£$} & \multicolumn{4}{|c|}{ Females } & \multicolumn{4}{|c|}{ Males } & \multirow[b]{2}{*}{$E$} \\
\hline & $\begin{array}{c}0 \text { to } \\
12 \mathrm{M}\end{array}$ & $\begin{array}{l}12 \text { to } \\
24 \mathrm{M}\end{array}$ & $\begin{array}{l}24 \text { to } \\
36 \mathrm{M}\end{array}$ & $\begin{array}{c}>36 \\
M\end{array}$ & $\begin{array}{c}0 \text { to } \\
12 \mathrm{M}\end{array}$ & $\begin{array}{l}12 \text { to } \\
24 \mathrm{M}\end{array}$ & $\begin{array}{l}24 \text { to } \\
36 \mathrm{M}\end{array}$ & $\begin{array}{c}>36 \\
M\end{array}$ & & $\begin{array}{c}0 \text { to } \\
12 \mathrm{M}\end{array}$ & $\begin{array}{l}12 \text { to } \\
24 \mathrm{M}\end{array}$ & $\begin{array}{l}24 \text { to } \\
36 \mathrm{M}\end{array}$ & $\begin{array}{c}>36 \\
M\end{array}$ & $\begin{array}{c}0 \text { to } \\
12 \mathrm{M}\end{array}$ & $\begin{array}{l}12 \text { to } \\
24 \mathrm{M}\end{array}$ & $\begin{array}{l}24 \text { to } \\
36 \mathrm{M}\end{array}$ & $\begin{array}{c}>36 \\
M\end{array}$ & \\
\hline Aquidauana & 13 & 9 & 8 & 38 & 11 & 9 & 6 & 5 & 100 & 12 & 15 & 7 & 26 & 11 & 17 & 7 & 6 & 100 \\
\hline Corumbá & 12 & 9 & 8 & 45 & 9 & 6 & 4 & 6 & 100 & - & - & - & - & - & - & - & - & - \\
\hline Ladário & 10 & 15 & 7 & 34 & 13 & 5 & 8 & 9 & 100 & - & - & - & - & - & - & - & - & - \\
\hline Miranda & 9 & 8 & 9 & 29 & 8 & 13 & 7 & 17 & 100 & 12 & 13 & 8 & 28 & 12 & 15 & 7 & 4 & 100 \\
\hline Coxim & 13 & 11 & 9 & 46 & 11 & 4 & 4 & 3 & 100 & 11 & 13 & 7 & 23 & 13 & 19 & 8 & 5 & 100 \\
\hline P. Murtinho & 11 & 9 & 8 & 32 & 10 & 12 & 10 & 8 & 100 & 10 & 15 & 11 & 31 & 9 & 13 & 6 & 5 & 100 \\
\hline
\end{tabular}


However, the adaptive condition of land use according to the annual pulse of floods makes it difficult to adopt a single management plan for wetlands and even for properties. This variation in the carrying capacity of a pasture prevents a fixed stocking rate for large area units. As a solution, the authors propose the mapping of landscape units that recognize temporary elements of the landscape (which flood at some times of the year, such as bays and ebb), greater attention to the size of each landscape unit and the variation of the support capacities of each type of vegetation, associated with the extent, intensity and frequency of annual floods [36].

Table 2 shows the destination of the flows of the animals that left the South Pantanal between 2007 and 2014. Clearly, it is possible to perceive that most remained in the pantanal wetlands; more than 6,300,000 cattle. As a complement and revealing the articulation between the plain and plateau areas in the BAP, 10.15 million heads were moved to the plateau, of which 4.2 million were sent to the plateau sub-regions of the seven municipalities (41\%) and 5.95 million $(59 \%)$ for other municipalities in the Basin.

Table 2. Number of cattle moved from the South Pantanal in the period from 2007 to 2014, according to the origins and the destinations (units).

\begin{tabular}{|c|c|c|c|c|c|c|c|}
\hline \multirow{3}{*}{\multicolumn{2}{|c|}{$\begin{array}{c}\text { Municipality and } \\
\text { Sub-Region of Origin }\end{array}$}} & \multicolumn{6}{|c|}{ Destinations } \\
\hline & & \multicolumn{2}{|c|}{ South Pantanal } & \multirow{2}{*}{$\begin{array}{l}\text { Others Municipality } \\
\text { in UPB }\end{array}$} & \multirow{2}{*}{$\begin{array}{c}\text { Paraná } \\
\text { Basin }\end{array}$} & \multirow{2}{*}{$\begin{array}{l}\text { Other } \\
\text { States }\end{array}$} & \multirow{2}{*}{ Total } \\
\hline & & Plain & Plateau & & & & \\
\hline \multirow{2}{*}{ Aquidauana } & Plain & 774,079 & 366,305 & 877,836 & 164,231 & 3384 & $2,185,835$ \\
\hline & Plateau & 90,854 & 202,696 & 431,679 & 55,537 & 14,656 & 795,422 \\
\hline Corumbá & Plain & $3,524,182$ & 883,993 & $1,255,910$ & 344,832 & 6614 & $6,015,531$ \\
\hline Coxim & Plateau & 91,133 & 772,726 & 535,658 & 218,940 & 28,815 & $1,647,272$ \\
\hline Ladário & Plain & 53,707 & 11,237 & - & - & - & 64,944 \\
\hline \multirow{2}{*}{ Miranda } & Plain & 175,289 & 58,653 & 203,152 & 14,329 & 2121 & 453,544 \\
\hline & Plateau & 192,744 & 419,636 & 551,265 & 86,088 & 2370 & $1,252,103$ \\
\hline $\begin{array}{c}\text { Rio Verde } \\
\text { de MT }\end{array}$ & Plateau & 113,134 & 509,725 & 501,189 & 144,261 & 8035 & $1,276,344$ \\
\hline \multicolumn{2}{|c|}{ Total } & $6,349,619$ & $4,197,292$ & $5,959,606$ & $1,637,188$ & 113,549 & \\
\hline
\end{tabular}

Source: Araujo (2018).

In the transhumance and in the outflow of the cattle breeding production, it is observed that old forms, such as the fluvial transport and the displacement on foot via means of cattle drovers grouped together (comitivas boiadeiras) are still performed. Despite the growing trend of trucking, whether it is through the mail to other farmers or in the direct sale to the slaughterhouses, the displacement on foot is predominant [10,36,37]. Taking Corumbá as an example, in the year 2014, almost 495,000 cattle were displaced on foot and almost 379,000 were displaced by road transport, according to the records [33].

The dynamics of this displacement reveal a dense movement of coming and going that reinforces the narrative of movement and fluidity as adaptive strategies of Pantanal livestock. As an illustration of this inherent mobility of regional bovine animals, Table 3 shows the volumes of cattle displaced according to the mode of transport. From the total of 32.163 .331 million cattle in the period, it is possible to see the predominance of road transport (56.38\%) and foot (39.37\%) as the most used in the South Pantanal.

In 2014 alone, almost 891,000 bovines left the South Pantanal "on foot" [32]. The trips on foot are made in cattle drovers grouped together and the distances traveled achieve hundreds of kilometers and can take months. Maneuvers are conducted by pedestrians who use the landings along the routes, places established in ports or farms that act as stopping points for river and/or land embarking, rest and replenishment in road and ways. 
Table 3. Number of cattle moved in South Pantanal between 2007 and 2014, according to the type of transport used.

\begin{tabular}{cc}
\hline Mean os Transportation & Total \\
\hline Road & 18.134 .450 \\
On foot & 12.661 .460 \\
On foot/Road (combined) & 670.164 \\
Road/fluvial (combined) & 529.960 \\
Others & 167.297 \\
Total & $\mathbf{3 2 . 1 6 3 . 3 3 1}$ \\
\hline
\end{tabular}

Source: Adapted from Araujo et al. (2016a).

As verified by IAGRO and the local producers, each property that acts as a landing or boat dock provides a corridor for the transit and rest of the herds, which involves shade of trees, pastures, and drinking water. Such practices do not involve official payments or regulation, they symbolize autonomous initiatives and possible socio-political actions of agents who end up having visibility for such a feat.

The existence of these landings expresses a cultural element of Pantanal cattle breeding that continues until today and forms another network-territory in these spaces [33]. Territory formed by all these points, shared only with other coincident commissions, at least with the owner of each place, configuring a form of temporary appropriation and also a symbolic one not related to the ownership of the land.

Figure 7 spatializes the landings recognized in 2014 by the state. The location in central areas of Corumbá and, in the other municipalities, in the bordering regions of the wetlands is remarkable. This arrangement suggests the behavior of the territory in motion [7] of cattle drovers grouped together, who exercise a "nomadic" territoriality in these places, coming from the more peripheral areas of the plain, if they use these places to rest and to travel. Likewise, the concentration of landings in other municipalities confirms the territorial logic of coming and going beyond South Pantanal, towards other municipalities of the highlands of the State of Mato Grosso do Sul.

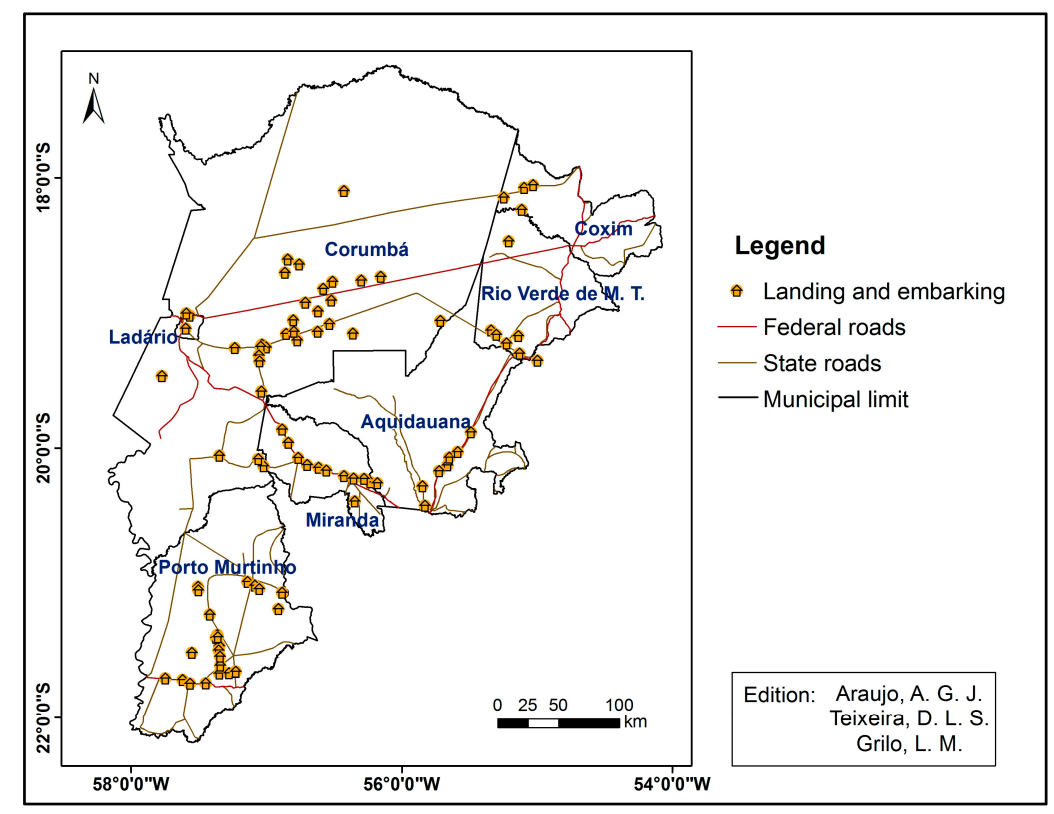

Figure 7. Landing points and rivers—with limits between plain/plateau. Source: Araujo (2018). 


\section{Conclusions}

In the context of the production systems of the Pantanal livestock, each farm represents a territory, space used by livestock, a use that varies according to the supply of resources and access to the channels of circulation and commercialization of the animals. In this organization, it is common to own more than one farm and administrative management integrates different areas of a farm or different farms that form a territory, articulated as a network, or a so called territory-network type. Besides management reasons, territorial articulation in network will also happen through occupation of temporary spaces in reason of foot traveling by cattle drovers grouped together (locally called comitivas boiadeiras).

Results in terms of flow and circulation revealed an intense pattern of cattle transit, with intra-regional variations, between plain and plateau and among municipalities. The logic of these movements is configured as a historically developed strategy of management and commercialization of cattle breeding, which extrapolates political-administrative limits and it is done mainly through foot and road transport.

Mapping of cattle territories in the South Pantanal identified a scenario of multiterritoriality. It was observed that the Pantanal cattle breeding maintains its "nursery" profile; however, it presents more intensive arrangements with rearing and fattening, mainly in the subregions and plateau of the municipalities. New territorialities represented by external agents and fragmentation of old properties mean a new mapping of the "used spaces" for cattle breeding in the South Pantanal.

This scenario indicates the need for future analysis by illustrating new power relations that delimit the region, and in environmental terms, to challenge the maintenance of traditional "nomad" logic, adapted to annual seasonal floods, since man-made "new fences" can implicate restrictions of access and circulation, increasing cattle vulnerability and risking the collapse of Pantanal cattle production.

Author Contributions: Conceptualization, A.G.J.A.: conceptualization, methodology, investigation and writing-original draft preparation and supervision. A.M.V.M.: conceptualization, methodology, validation, formal analysis, writing-review \& editing and supervision. L.T.S.: conceptualization, methodology, validation, formal analysis and writing-review \& editing. G.S.O.: methodology, formal analysis and supervision. L.M.G.: Software, investigation and Writing-Original Draft Preparation. D.L.S.T.: Software, investigation and Writing-Original Draft Preparation. M.T.S.: Validation, Software, investigation and Writing-Original Draft Preparation.

Funding: We gratefully recognize the Coordination for the Improvement of Higher Education Personnel foundation (CAPES/Brazil) for the first author's scholarship.

Acknowledgments: We gratefully recognize the Coordination for the Improvement of Higher Education Personnel foundation (CAPES/Brazil) for the first author's scholarship and thank the State Agency of Sanitary Monitoring (IAGRO) for the cattle transit data, Olinda Barbosa Marques de Souza (retired as Secretary of Production and Tourism of the State of Mato Grosso do Sul) for advice on discussions, readings, and notes.

Conflicts of Interest: The authors declare no conflict of interest.

\section{References}

1. De Castro, J. The Geopolitics of Hunger. In Modern Reader Paperbacks, 2nd ed.; Monthly Review Press: New York, NY, USA, 1952; 348p. (In Portuguese)

2. United Nations Organization (UNO). World Population Prospects: The 2017 Revision, Key Findings and Advance Tables; Working Paper No. ESA/P/WP/248; United Nations Organization: New York, NY, USA, 2017; 53p.

3. European Academies Science Advisory Council (EASAC). Extreme Weather Events in Europe-Preparing for Climate Change Adaptation: An. Update on EASAC's 2013 Study; European Academies Science Advisory Council: Halle, Germany, 2018.

4. BRASIL IBGE. Statistics-Research on Municipal Livestock Production (PPM) 2015. Available online: http:/ / www.ibge.gov.br/home/estatistica/economia/agropecuaria/censoagro/default.shtm (accessed on 20 December 2015). (In Portuguese) 
5. Junk, W.J.; Wantzen, K.M. The flood pulse concept: New aspects, approaches, and applications-an update. In Proceedings of the Second International Symposium on the Management of Large Rivers for Fisheries, Food and Agriculture Organization \& Mekong River Commission, 2nd ed.; Welcomme, R.L., Petr, T., Eds.; FAO Regional Office for Asia and the Pacific: Bangkok, Thailand, 2004; pp. 117-149.

6. Da Silva, J.S.V.; De Abdon, M.M. Delimitation of the Brazilian Pantanal and its sub-regions. Revista Pesquisa Agropecuária Brasileira: Brasília 1998, 33, 1703-1711. (In Portuguese)

7. Abreu, U.G.P.; Rosa, A.N.; Sereno, J.R.B.; Santos, S.A. Melhoramento genético. In Cattle cut in the Pantanal: The Producer Question, Embrapa Responds; Cardoso, E.L., Ed.; Embrapa Informação Tecnológica: Brasília, Brazil, 2004; pp. 171-185. (In Portuguese)

8. Araujo, A.G.J. Influence of Hydrometeorological Variability on the Territorial Logics of Livestock in the Pantanal, Mato Grosso do Sul, Brazil. Ph.D. Thesis, INPE, São José dos Campos, Brazil, 2018. (In Portuguese)

9. Araujo, A.G.J.; Silva, L.T.; Santos, L.B.L.; Silva, B.M.M.; Oliveira, G.S.; Obregón, G.O.; Monteiro, A.M.V.; Lemes, M.C.R.; Prado, M.L.; Rodriguez, D.A. The flow of beef cattle in the Pantanal Sul: An analysis of the cattle traffic investigating the interference of the hydro meteorological dynamics of the region and the extreme event "full of 2011". In Simpósio de Geotecnologias no Pantanal, 6th ed.; Anais: Cuiabá, Brazil, 2016; pp. 442-452. (In Portuguese)

10. Pott, A. Ecossistema Pantanal. In Use and Pasture Management; Puignau, J.P., Ed.; IICA-PROCISUR: Montevideo, Uruguay, 1994; pp. 31-44. (In Portuguese)

11. Abreu, U.G.P.; Mcmanus, C.; Santos, A.S. Cattle ranching, conservation and transhumance in Brazilian Pantanal. Pastor. Res. Policy Pract. 2010, 1, 99-114.

12. Araujo, A.P.C.; Vargas, I.A.D.; Bicalho, A.M.D.S.M. The traditional cattle ranches of the Mato Grosso Pantanal and the spatial order. In Dynamics of Contemporary Rural; Araujo, A.P.C., Vargas, I.A., Eds.; EDUFMS: Campo Grande, Brazil, 2014; pp. 231-250. (In Portuguese)

13. Corrêa, E.S.; Paim, F.C.; Melo Filho, G.A.; Pereira, M.A. Improved Production Systems for Cattle in Mato Grosso do Sul; Embrapa Gado de Corte: Campo Grande, Brazil, 2006. (In Portuguese)

14. De Pereira, M.A.; Costa, F.P.; Malafaia, G.C.; Cardoso, E.E.; Da Vieira, J.S. Cost of Cutting Cattle Production in Mato Grosso do Sul Part I: Low Technological Level; Embrapa Gado de Corte: Campo Grande, Brazil, 2014. (In Portuguese)

15. Carvalho, T.B.; Abreu, U.P.G.; Almeida, B.S.; Zen, S. Production Cost in Cutting Cattle in 2009, in the Pantanal of Corumbá (MS); Embrapa Pantanal: Corumbá, Brazil, 2010; p. 6. (In Portuguese)

16. Santos, S.A.; Pellegrin, A.O.; Moraes, A.S.; Barros, A.T.M.; Comastri Filho, J.A.; Sereno, J.R.B.; Santos, E.; Silva, R.A.M.; Abreu, U.G.P. Production System 01: Pantanal Cattle Production System; Embrapa Pantanal: Corumbá, Brazil, 2002; pp. 21-35. (In Portuguese)

17. Esselin, P.M. The Livestock Cattle in the Process of Occupancy and Economic Development of the Pantanal Sul-Mato-Grossense (1830-1910); UFGD: Dourados, Brazil, 2011; 358p. (In Portuguese)

18. Araujo, A.P.C.; Bicalho, A.M.S.M. The Rural in Motion: Livestock in the Spatial Transformations of the Pantanal; Editora UFMS: Campo Grande, Brazil, 2010. (In Portuguese)

19. Vargas, I.A.D. Haunted Portraits of Paradise: Socioenvironmental Sustainability Attacks of the Pantanal; Editora UFMS: Campo Grande, Brazil, 2009; 304p. (In Portuguese)

20. Souza, M.L. "Territory" of divergence (and confusion): Around the imprecise of a fundamental concept. In Geography: Concepts and Topics; de Castro, I.E., da Costa Gomes, P.C., Corrêa, R.L., Eds.; Bertrand Brasil: Rio de Janeiro, Brazil, 2009; pp. 77-116. (In Portuguese)

21. Haesbaert, R. The Myth of Desterritorialization: From the "end of territories" to Multiterritoriality; Bertrand Brasil: Rio de Janeiro, Brazil, 2004. (In Portuguese)

22. Haesbaert, R. Territory and multiterritoriality: A debate. Geographia 2007, 9, 19-46. (In Portuguese)

23. Haesbaert, R. Of space and territory, structure and process. Economía Sociedad Y Territorio 2013, 13, 805-815. (In Portuguese)

24. Haesbaert, R. Logical zone and territorial ordering: To rediscuss Proximity and spatial contiguity. Cultura E Representações Sociais 2014, 8, 9-29. (In Spanish)

25. Haesbaert, R. Limits in space-time: The resumption of a debate. Revista Brasileira De Geografia 2016, 61, 5-20. (In Portuguese) 
26. Coelho Neto, A.S. Defining Components of the Territory Concept: Multiscalarity, Multidimensionality and the Space-Power relation. Geographia 2013, 15, 23-52. (In Portuguese)

27. Agência de Defesa Sanitária Animal e vegetal do Estado de Mato Grosso do Sul (IAGRO). Reports on Transit of Cattle from Mato Grosso do Sul 2007 to 2014; Data Provided; Animal and Plant Health Agency of the State of Mato Grosso do Sul: Campo Grande, Brazil, 2015. (In Portuguese)

28. Silva, J.S.V.; Pott, A.; Abdon, M.M.; Pott, V.J.; Santos, K.R. GeoMS Project: Plant Cover and Land Use in the State of Mato Grosso do Sul; Embrapa Informática Agropecuária: Campinas, Brazil, 2011; 64p. (In Portuguese)

29. Abreu, U.G.P.; Bergier, I.; Paim, F.C.; Oliveira, L.O.F.; Nogueira, E.; Silva, J.C.B.; Schiavi, D.; Silva, C., Jr. Intensive Production System in the Brazilian Tropical Region: The Case of the Pantanal; Embrapa Pantanal: Corumbá, Brazil, 2018; 26p. (In Portuguese)

30. BRASIL IBGE. Agricultural Census 2006. 2006. Available online: http://www.ibge.gov.br/home/estatistica/ economia/agropecuaria/censoagro/default.shtm (accessed on 20 January 2016).

31. Animal and Plant Health Defense Agency of Mato Grosso do Sul State (IAGRO). Law $N^{\circ} 3.505$; Official Printing Office of the Mato Grosso do Sul State: Campo Grande, Brazil, 2015. (Original Publication).

32. Brasil Ministry of Agriculture, Livestock and Food Supply. Law $N^{\circ}$ 5.741; Government Printing Office-Section 1: Brasília, Brazil, 2006. (Original Publication).

33. Araujo, A.G.J.; Silva, L.T.; Silva, D.G.; Novaes Júnior, R.A.; Silva, R.G.N.; Prado, M.L.; Lemes, M.C.R.; Nascimento, L.N.; Masuda, N.F.S.; Monteiro, A.M.V.; et al. The area of beef cattle in the Pantanal of Mato Grosso do Sul: Networks, territories and territorialities. In Symposium on Geotechnology in the Pantanal, 6th ed.; Anais: Cuiabá, Brazil, 2016. (In Portuguese)

34. Araujo, A.; Silva, L.T.D.; Monteiro, A.M.V.; Rodriguez, D.A. The Territories of cattle breeding cattle in the Pantanal Sul Mato-Grossense: From the nomadism of the Guaicurus the multiplicity of the present days. In International Congress of Regional History, 1st ed.; AGB/ANPUH-MS; Anais: Aquidauana, Brazil, 2016. (In Portuguese)

35. Rosa, A.N.; Abreu, U.G.P.; Silva, L.O.C.; Nobre, C.; Gondo, A.P.R.C.V. Cattle Breeding in the Brazilian Pantanal: Reality and Future Prospects for Breeding; Embrapa Pantanal: Corumbá, Brazil, 2007; p. 18. (In Portuguese)

36. Queiroz Neto, J.P. Dynamics of a Pantanal Landscape: Nhecolândia. In Research Relatory FAPESP; Universidade de São Paulo: SãoPaulo, Brazil, 1999. (In Portuguese)

37. D'Oliveira, M.C.; Souza, M.I.L.; Corrêa Filho, R.A.C.; Morais, M.D.G.; ÍTAVO, C.C.B.F.; Franco, G.L. Effects of road transportation or droving on the weight and metabolism of young bulls. Trop. Anim. Health Prod. 2014, 46, 1447-1453. [CrossRef] [PubMed] 